\section{Michigan Technological

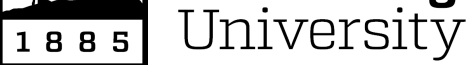

Michigan Technological University Digital Commons @ Michigan Tech

$3-1-2012$

\title{
Community Voices: Perspectives on Renewable Energy in Nunavut
}

Nicole C. McDonald

Queen's University

Joshua M. Pearce

Michigan Technological University

Follow this and additional works at: https://digitalcommons.mtu.edu/materials_fp

\section{Recommended Citation}

McDonald, Nicole C., \& Pearce, Joshua M. (2013). Community Voices: Perspectives on Renewable Energy in Nunavut. Arctic, 66(1), 94-104. http://digitalcommons.mtu.edu/materials_fp/8 


\title{
Community Voices: Perspectives on Renewable Energy in Nunavut
}

\author{
NICOLE C. McDONALD ${ }^{1}$ and JOSHUA M. PEARCE ${ }^{2}$
}

(Received 27 April 2011; accepted in revised form 5 June 2012)

\begin{abstract}
Nunavut communities currently depend on imported diesel fuel for virtually all of their energy needs. This dependency not only hinders the ability of communities to be self-sufficient, but also has negative impacts on their environment, health, and social well-being. The current practices waste $65 \%$ of the energy created and place a serious economic strain on the society by consuming $20 \%$ of the government's annual budget. Although renewable energy technologies (RETs) could partially offset diesel use, there is a lack of sufficient information to mold appropriate policy. This investigation of community perspectives contributes to information needed to develop sustainable energy policies for Nunavut. Open-ended interviews with approximately 10 members from each of three communities were studied using logical analysis, pattern coding, and content analysis. The respondents' greatest concerns about energy in Nunavut are the impacts of technology on the environment and the economy and the lack of government initiatives to explore RETs. In identifying these concerns, respondents expressed an overwhelming need to protect their land and wildlife, likely stemming from Nunavut's dominant Inuit culture. Moreover, Nunavummiut generally supported wind and solar power in their community, but greatly opposed hydropower, though some of these views on hydropower might shift if better information were available to residents. Finally, respondents suggested a variety of community-accepted actions that could be used to increase RET expansion in Nunavut. These actions fit into four categories: policy development, economics, suitable RETs, and capacity and knowledge building.
\end{abstract}

Key words: Nunavut, renewable energy policy, community-based research, photovoltaic, wind energy, hydropower, renewable energy, energy, solar energy, electricity

RÉSUMÉ. À l'heure actuelle, les collectivités du Nunavut dépendent du carburant diesel importé pour répondre à presque tous leurs besoins en énergie. Non seulement cette dépendance empêche-t-elle les collectivités d'être autosuffisantes, mais elle a également des effets négatifs sur l'environnement, la santé et le bien-être social de ces collectivités. Les habitudes actuelles ont pour effet de gaspiller $65 \%$ de l'énergie produite, en plus d'imposer de sérieuses contraintes économiques sur la société en raison de la consommation de $20 \%$ du budget annuel du gouvernement. Bien que les technologies des énergies renouvelables permettent de compenser une partie de l'utilisation du diesel, il n'existe pas d'information suffisante pour formuler une politique adéquate. L'étude réalisée dans le but de connaître les perspectives des collectivités fournit l'information nécessaire à l'élaboration de politiques d'énergies durables pour le Nunavut. Des entretiens en profondeur effectués avec environ dix membres de chacune des trois collectivités ont fait l'objet d'une analyse rationnelle, d'une codification des tendances et d'une analyse de contenu. Les plus grandes préoccupations des répondants au sujet de l'énergie au Nunavut concernent les incidences de la technologie sur l'environnement et l'économie, ainsi que l'absence d'initiatives de la part du gouvernement pour explorer les technologies des énergies renouvelables. En nommant leurs préoccupations, les répondants ont eu l'occasion d'exprimer l'importante nécessité de protéger leur terre et leur faune, ce qui est probablement attribuable à la culture inuite dominante du Nunavut. De plus, les Nunavummiut se montraient généralement en faveur de l'énergie éolienne et de l'énergie solaire au sein de leur collectivité, mais ils s'opposaient fortement à l'hydroélectricité, quoiqu'ils pourraient être aptes à changer d'avis s'ils avaient accès à de la meilleure information. Et enfin, les répondants ont suggéré une variété de mesures acceptées par la collectivité, mesures qui pourraient permettre d'intensifier la présence de technologies des énergies renouvelables au Nunavut. Ces mesures relèvent de quatre catégories soit l'élaboration de politiques, l'économie, des technologies des énergies renouvelables adéquates de même que l'acquisition de la capacité et de connaissances.

Mots clés : Nunavut, politique des énergies renouvelables, recherche communautaire, photovoltaïque, énergie éolienne, énergie hydroélectrique, énergie renouvelable, énergie, énergie solaire, électricité

Traduit pour la revue Arctic par Nicole Giguère.

\footnotetext{
${ }^{1}$ Queen's University, Faculty of Law, 128 Union Street, Kingston, Ontario K7L 3N6, Canada; 9nm@queensu.ca

${ }^{2}$ Corresponding author: Department of Materials Science \& Engineering and Department of Electrical \& Computer Engineering, Michigan Technological University, 601 M\&M Building, 1400 Townsend Drive, Houghton, Michigan 49931-1295, USA; pearce@mtu.edu

(C) The Arctic Institute of North America
} 


\section{INTRODUCTION}

Nunavut, like many other circumpolar regions, faces a number of significant challenges to its long-term sustainability due to ongoing pressures from modernization and development, which have led communities to become dependent on imported diesel fuel to provide electricity, transportation, and heat energy (GN, 2007a, b). This dependency not only hinders the ability of communities to be self-sufficient, but also has a negative impact on their health, their social and economic well-being, and the environment and land upon which Inuit depend (GN, 2010). As diesel prices, energy consumption, and infrastructure needs increase in the future, Nunavut will face even greater challenges to establishing self-sufficient and healthy communities (GN, 2007a, b, 2010).

One promising solution to enable Nunavut communities to become more energy independent while decreasing the negative impact of diesel fuel is to develop renewable energy technology (RET) projects in communities (St. Denis and Parker, 2009). The Qulliq Energy Corporation (QEC) has tested wind turbines in three communities (Nunavut Power, 2002), but even though the use of RETs has grown globally, no significant effort has been made by the federal or territorial government to integrate RETs into Nunavut communities (GN, 2007b; Arent et al., 2011). While the GN (2007a) has published an ambitious territorial energy strategy, Ikummatiit: The Government of Nunavut Energy Strategy, it has yet to implement it.

The Government of Nunavut programs, services, and policy development are guided by the spirit of Inuit Qaujimajatuqangit (traditional knowledge) and the principles of Aajiiqatigiingniq (consensus decision-making), Piliriqatigiingniq (working together for a common purpose), Qanuqtuurungnarniq (being resourceful to solve problems), and Avatittinnik Kamatsiarhiq (environmental stewardship) (GN, 2005, 2007a). Thus, the Government of Nunavut has a strong focus on community consultations and values the perspectives of Nunavummiut. In order to develop responsive and appropriate renewable energy policy in Nunavut, it is therefore essential that policy-makers have a clear understanding of Nunavummiut perspectives on renewable energy technologies (GN, 2005, 2007a). Moreover, policies that take into account the environmental, cultural, economic, and educational context of the communities are more likely to be effective and sustainable, while simultaneously gaining community approval (Hall, 1992; Loka Institute, 2002; Pearce, 2006). This study explores the perspectives of Nunavummiut on the current energy situation in their communities, as well as potential future RET projects, to support the design of future sustainable energy policies for Nunavut. It uses open-ended qualitative interviews, which are analyzed using logical analysis, pattern coding, and content analysis. After presenting and analyzing results, it identifies actions that can be taken by government to increase community acceptance of RET projects and policies in Nunavut.

\section{BACKGROUND}

\section{Nunavut}

Nunavut, Canada's newest territory, is located primarily north of $60^{\circ}$ (Fig. 1) and encompasses about one-fifth of Canada's landmass (GN, 2008). The territory, with a population that is $85 \%$ Inuit, is predominantly influenced by Aboriginal culture. As a result, there is a strong traditional and cultural attachment to Nunavut's land, water, and wildlife (GN, 2010). Because of this tradition, there is a significant dependence on food harvested from the local environment, which galvanizes community concerns about sources of contamination from hydro or nuclear power.

In 2009, Nunavut's population was about 32200 , spread across more than 20 remote communities ranging in size from 150 to about 7000 residents (GN, 2009, 2010). Residents of these remote communities face a number of challenges, including a lack of transportation infrastructure: no two communities are connected by road or rail (GN, 2009). Consequently, the territory has a very strong reliance on importing almost everything from the South using sealift (large-scale transportation by sea) or aircraft (Joint Ventures Ltd., 2003). The extreme and inclement weather conditions that are routine in the territory compound this isolation (GN, 2003), and the northern latitude means that communities face varying "light" and "dark" seasons throughout the year, as the number of sunlight hours that a community experiences daily varies each month (GN, 2009).

\section{Current Nunavut Energy Situation}

In Nunavut, communities have developed a strong dependence on diesel fuel for their energy needs, which include electricity, heat, and transportation (GN, 2007a). However, as this research focuses primarily on shifting electricity sources in Nunavut from diesel to renewable energy, the current electricity situation in Nunavut will be our main topic of discussion.

Currently, the QEC provides electricity to the remote Nunavut community grids through 26 diesel plants (London Economic Press, 2004; GN, 2007a, b; QEC, 2011a). These inefficient generators waste about $65 \%$ of the energy produced, although it should be noted that QEC has installed waste heat recovery systems in two communities and could significantly improve the energy efficiency of the systems in other communities by doing the same in the remaining plants (GN, 2007, 2009).

The Government of Nunavut estimated that it spends about one-fifth of its annual budget on the energy needs of the territory (GN, 2007a, b, 2010). Moreover, in 2007-08, the GN spent about $\$ 40.4$ million on direct energy subsidies, a large portion of which supported the energy subsidy given to public housing residents (GN, 2010). The stress of paying for electricity in Nunavut can also be seen at the community level, where electricity rates climbed $19 \%$ in 


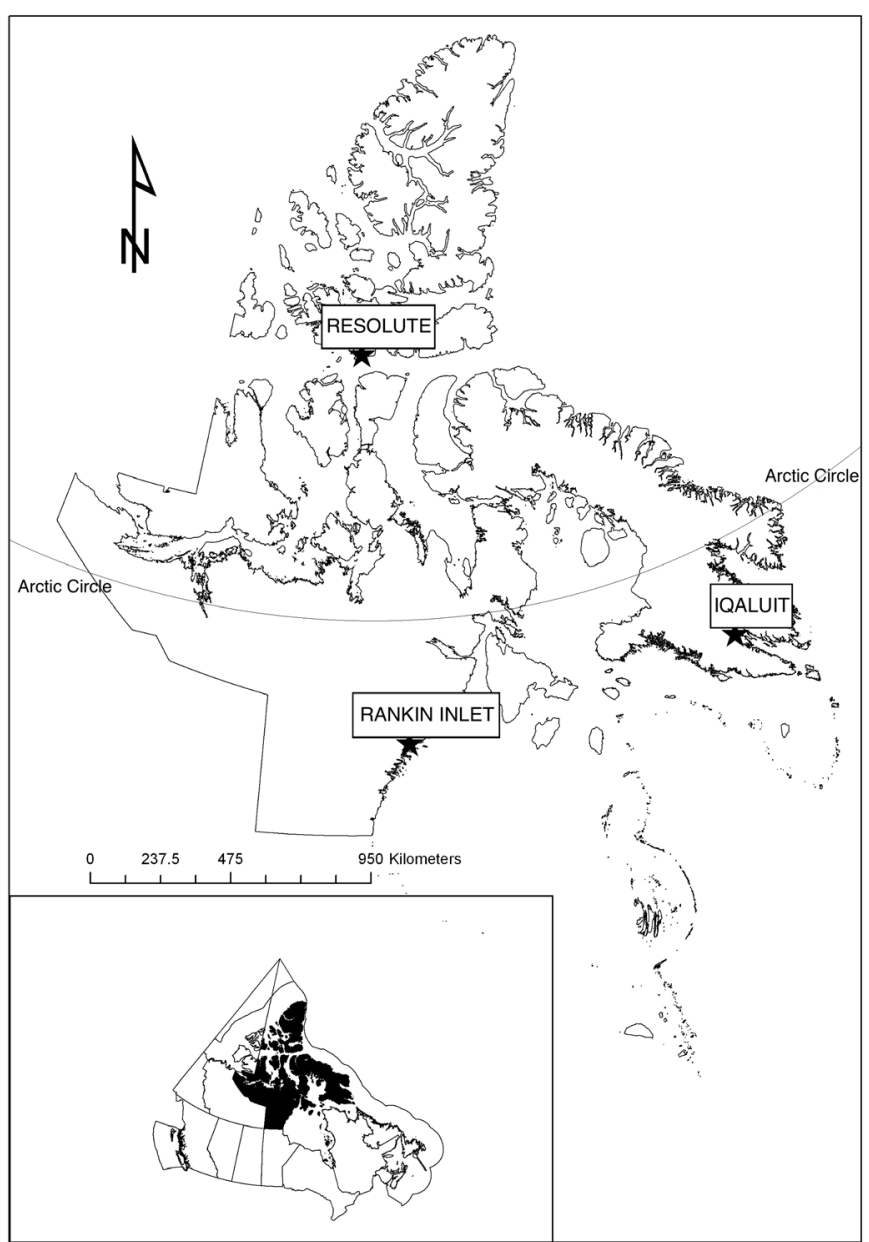

FIG. 1. Map of Nunavut.

2011 and reached $\$ 1.02 / \mathrm{kWh}$ in one community, compared to $11 \varnothing / \mathrm{kWh}$ in Ontario (GNWT, 2008; CBC, 2011a; QEC, 2011b). This ongoing economic stress has limited the GN's ability to address other pressures, including housing, education programs, health services, and food security (NTI, 2008, 2009; GN, 2009, 2010; Egeland et al., 2010).

In addition to economic stress on the territory, a number of environmental and health impacts are associated with diesel use. Diesel spills in Nunavut have been linked to land degradation and wildlife contamination, two issues that directly oppose the strong Inuit culture in Nunavut of respecting and protecting the environment (GN, 2008). Cases of diesel being spilt during shipping or fuel tankers running aground are also constant hazards associated with diesel dependency in Nunavut (GN, 2009). Diesel use produces extensive emissions, which have been linked to lower air quality and higher rates of asthma among community members (Boulet et al., 1999; CACP, 1999; Abelsohn et al., 2002; Weir, 2002; Ciencewicki and Jaspers, 2007; Sigaud et al., 2007). Finally, even the efficient burning of diesel fuel releases carbon dioxide, a known greenhouse gas that contributes to global climate change (IPCC, 2008). In Nunavut, temperatures, precipitation, the length of the seasons, the direction and strength of winds, and the predictability of the weather have all been affected by this climate destabilization (GN, 2001; NTI, 2001; Ford and Smit, 2004). Despite their relatively small contribution to greenhouse gas emissions, the residents of Nunavut have the highest per capita rates of greenhouse gas exposure in Canada, and among the highest in the world (GN, 2003). These gases further contribute to environmental degradation and threaten the traditional Inuit culture in Nunavut (Freeman and Carbyn, 1988). However, their presence provides the territory with the opportunity to show tremendous leadership on greenhouse gas reductions.

\section{Renewable Energy Technologies}

Renewable energy technologies (RETs), which derive energy from natural processes such as sun, wind, and marine resources that are constantly replenished (Janssen and IEA Renewable Energy Working Party, 2002), have been used in many remote communities to shift the primary energy source away from diesel (St. Denis and Parker, 2009). In Canada, many communities have already begun to develop policies and programs that support RET expansion, such as the FIT program in Ontario and Nova Scotia (OPA, 2008, 2010; Smitherman, 2009; Nova Scotia Department of Energy, 2010). Aboriginal communities can also use these programs as a potentially powerful means of economic development (McLaughlin et al., 2010). Nonetheless, Nunavut still lags behind in this area (GN, 2007a). Though Nunavut established a handful of RETs in Rankin Inlet, Cambridge Bay, Kugluktuk, and Iqaluit in the 1980s and 1990 s, the systems used outdated technologies that have not proven to be very successful in the North (NRCan, 1998; Ascher, 2002; Nunavut Power, 2002; GN, 2007b). However, new technology has been developed and tested successfully in other northern regions, making RETs a promising solution for Nunavut communities as they begin the transition to a more sustainable energy plan (Ross and Usher, 1995; Dignard-Bailey et al., 1998; Tammelin and Seifert, 2001; GN, 2007a; Windeyer, 2010).

Given the natural resources in Nunavut, the three most promising technologies that could be deployed in communities are solar photovoltaic (PV) technology, wind turbines, and run-of-river hydropower (GN, 2007a). Solar PV technology converts sunlight directly into electrical energy and provides the means for the basis of a sustainable energy system (Pearce, 2002). Wind energy is produced by harnessing and converting the kinetic energy of the wind into electricity using turbines that are mounted in areas that have favourable wind patterns (CanmetENERGY, 2009). Both PV and wind power are established forms of distributed generation whereby electric power is generated at various locations near the point of use, which makes them good candidates for Nunavut's geographically isolated communities (McDonald et al., 2012). Both are also modular and can be designed to match any size of electrical load. Finally, run-of-river hydroelectricity projects are dramatically different in design and appearance from conventional 
hydroelectric power plants. Traditional hydro dams store large quantities of water in reservoirs, necessitating the flooding of large areas of land. In Nunavut, such centralized electrical generation is neither necessary nor cost-effective, as each community has its own isolated distribution grid. However, since most run-of-river projects do not require a large dam or reservoirs for water storage and use the natural flow of rivers over turbines to create electrical energy, these systems are more appropriate for Nunavut and environmentally responsible (CanmetENERGY, 2005). Nonetheless, it should be noted that in order to have sufficient power density, these systems must have sufficient gradient, which may not exist in much of Nunavut. Moreover, since run-of-river systems depend on the flow of the river, these systems may need to be removed in the winter when most Nunavut rivers freeze to the bottom.

\section{METHODS}

To properly address the complexity of sustainable community-based development, it is essential to gain approval and buy-in from community members (Hall, 1992; Loka Institute, 2002). Qualitative, open-ended interviews offer an opportunity to learn participants' judgments and terminology and explore the complexities of their perceptions and experiences (Patton, 1990; Israel et al., 2005). This study used such interviews to explore Nunavummiut perspectives on the acceptability of RETs for their communities and to draw conclusions regarding how these perspectives could be used to help guide policy-makers as they develop future renewable energy policies in Nunavut.

\section{Data Collection}

In determining the pool of respondents for the interviews, three Nunavut communities, Iqaluit, Rankin Inlet, and Resolute Bay, were chosen for their location, population size, and accessibility. Seventeen local residents, 12 Inuit and five non-Inuit, were asked to participate in short, open-ended qualitative interviews. If the residents agreed, the interviews were digitally recorded for accuracy. Respondents were identified by reputation through personal contacts in the communities and on the recommendation of other researchers in the field (Laumann and Knoke, 1987). To ensure a variety of Nunavummiut perspectives, interviewees included both Inuit and non-Inuit residents, who resided in small and large communities across Nunavut and lived in diverse social conditions. However, while the interview results provide insight into how many Nunavummiut perceive renewable energy, they are not completely representative of the general public.

The primary interview method employed was the semistructured interview technique, which uses a predetermined set of questions, but varies the sequence and wording of the questions during the course of the interviews (Patton, 1990; Mikkelsen, 1995). In some cases, however, interviews used the informal conversational interview technique (Patton, 1990). Generally, interviews lasted for 10 to 30 minutes and aimed to determine community members' perspectives on diesel use in their community and their views on the potential introduction of RETs.

\section{Data Analysis}

Three qualitative data analysis methods were employed to explore the perspectives of Nunavummiut. First, pattern coding was used to identify the overarching concepts found in the interview results. These concepts helped separate the results of the interviews into four categories: (1) perceived impacts of diesel, (2) perspectives on renewable energy (3) perceived factors hindering renewable energy expansion, and (4) perceived potential positive and negative policy actions. Content analysis was then used to determine the frequency of use of local terms. This analysis allowed us to break down the four categories into sub-categories and assess what issues respondents consider most important to address as new policies are developed (Miles and Huberman, 1984; Patton, 1990). Finally, logical analysis was used to discuss the underlying themes within the interviews (Patton, 1990) that may have influenced participants' views on renewable energy use in Nunavut.

\section{RESULTS}

Pattern coding and content analysis identified a number of ideas discussed by the interviewees that reveal the various perspectives of Nunavut residents on diesel use and renewable energy expansion in their communities. These results are especially important in Nunavut to follow the spirit of Inuit Qaujimajatuqangit (IQ) and provide policymakers with an understanding of community concerns regarding RETs and steps that should be taken to gain community support or address community concerns.

\section{Impacts of Diesel Use on Nunavut Communities}

To understand the potential positive impact that respondents believe renewable energy may have in their community, it is important to explore the perceived impacts of current diesel use. Respondents were asked to describe the current electricity situation in their community and any impacts they have seen from it. The 17 residents identified five major impacts: 1) environmental impacts (11 responses), 2) economic impacts (7 responses), 3) total reliance on diesel or lack of back-up electricity and alternatives (5 responses), 4) noise pollution (2 responses), and 5) health impacts (1 response).

The impact most identified by residents was that of diesel on the environment; often described as the discharge of emissions into the communities, causing air pollution; however, some noted other environmental impacts such as fuel spills, brown smoke covering Frobisher Bay and blue smog 
surrounding fiords near Arctic Bay. Respondents identified these last two impacts as those they believe to be direct impacts of the emissions from the diesel generators.

The second most frequent impact that respondents discussed in their interviews was the perceived negative economic impact of diesel use on their communities. Generally residents said that the cost of electricity poses a serious economic stress on their day-to-day life. A mayor disclosed that in some extreme cases he has witnessed "people [going] with no clothes."

The third most mentioned impact, identified by five respondents, is the lack of back-up electricity options in the communities. As one Rankin Inlet resident explains, the virtually complete reliance on diesel fuel puts the community in a precipitous situation. Broken-down diesel generators have caused power outages in the middle of the winter because the Nunavut energy portfolio has no backup energy systems built into the isolated grid. Finally, respondents explained that because the QEC has a monopoly on Nunavut's utilities, there are no alternative (independent) energy sources for community members to choose from if they prefer not to use diesel-generated power.

Other impacts identified by respondents include noise pollution from the generators and various health impacts within the community. One Resolute Bay resident explains, "the power plant is...anti-Arctic in some ways because it makes a hell of a lot of noise!" Later, this same resident explained that in his opinion, the diesel generators have created a lower quality of air for people in the community, and that this is likely occurring across the territory.

Understanding the perceived impacts of diesel use on communities is important for two reasons. First, it provides policy-makers with an understanding of the concerns that Nunavummiut have with regard to RETs, information that can be used as a baseline to help guide new RET policies and programs as they are developed. Second, the fact that RETs would not cause the same concerns as diesel might make communities more likely to support them. This support is important, since sustainable, community-based development requires approval and buy-in from community members.

\section{Nunavummiut Perspectives on Renewable Energy Technologies}

The interviews showed that Nunavummiut perspectives on RETs (positive, negative, or no opinion) differed for the three types of technology (solar energy, wind energy, and hydropower). For solar energy, 9 respondents were positive, 7 were negative, and 1 had no opinion, and the comparable figures for wind energy were 11,5 , and 1 . Hydropower was viewed much more negatively, with only 6 positive and 11 negative responses.

Solar Energy: In discussing the use of solar energy in Nunavut, nine residents believed that it could be successful in their community, while seven felt that it should not be pursued as an alternative to diesel. In both cases, the discussion of solar energy focused largely on the solar resources that exist in Nunavut. Respondents who supported solar energy felt that it should be explored, given the excellent solar resources Nunavut has in summer, especially in the more northern communities, which experience 24-hour sunlight in the summer months. These respondents believed solar energy could be a viable option to offset diesel electricity in the summer months. Respondents who opposed solar energy focused on the lack of sunlight during the winter. They argue that if the technology cannot be used year-round, it is not worth pursuing.

Wind Energy: Respondents' views on wind energy were very similar to those on solar energy, in that they generally supported the development of wind energy in their communities. Eleven respondents expressed a positive disposition towards wind energy, while only five opposed it. Perspectives on wind energy were again shaped by the knowledge respondents had of wind resources in their local communities. Respondents from Iqaluit, Rankin Inlet, and Resolute Bay who supported wind energy argued that in their opinion, the strong and constant wind patterns in the region could be excellent conditions for successful wind energy production. Those who opposed wind energy believed that these strong wind patterns, combined with unpredictably cold temperatures $\left(-60^{\circ} \mathrm{C}\right.$ or colder) and extreme rain and snowstorms, would likely cause mechanical failures of the turbines. Often these concerns were based on unsuccessful wind turbine deployment in Nunavut in the past. One resident shared his experience with the wind turbine in Cambridge Bay, which he said broke down and eventually fell down because it had not been properly maintained after very strong winds had caused it to seize. Throughout the interviews, respondents who opposed wind energy referred to similar stories, indicating that these past failures have created a somewhat negative image of wind energy in Nunavut. However, respondents did explain that this negative representation could be undone if residents were exposed to the realities of wind energy in the North. Moreover, a former community mayor explained, "If we're going to look at the big picture, we shouldn't just eliminate one [technology] because one new technology didn't work... I think there's some newer [wind technologies] that [are] working."

Hydropower: Respondents were much more negative about hydropower, with 11 against it and only six supporting it. In general, those who did not support hydropower believed that it would have a negative impact on the land and wildlife. One respondent explained:

Look [at] what's happened in northern Quebec [and] Ontario - the Native people over there can't even eat their fish anymore. It's too full of mercury from the lands being flooded and the forest being flooded which put mercury and contaminants into the fish.

Other similar stories arose in the interviews, and respondents explained that they believe many other 
residents have come to disapprove of future hydropower development in the territory. However, a small number of respondents supported hydropower in Nunavut, mainly because they believe this energy source could provide the biggest electricity pay-off compared to other alternative energy sources.

\section{Factors Perceived as Hindering Renewable Energy Expansion in Nunavut}

An important step toward understanding the overall perspective of Nunavummiut on RETs, which is especially important in Nunavut, where IQ guides policies, is to identify the factors that residents perceive to hinder RET expansion in Nunavut. Respondents named six such factors: (1) RETS are costly (9 responses); (2) they are environmentally unfriendly (6 responses); (3) federal and territorial governments are not trying to find creative solutions (5 responses); (4) RET technology is not designed for the North (3 responses); (5) communities lack knowledge of RETS ( 3 responses) and (6) they also lack skills needed to maintain RET systems (1 response).

The main factor that Nunavummiut identified is the perceived high upfront capital cost of RET systems and the lack of available funding to support the necessary infrastructure needed for RET expansion. As one respondent explained:

\section{Nobody likes the current situation. However, because the cost of living, the cost of any kind of construction or infrastructure is so expensive here, we're caught between a rock and a hard place and the Nunavut government is already strapped for cash.}

Other respondents made similar statements, reinforcing the notion that they feel the cost of RETs and infrastructure development has been a major barrier to RET expansion.

The second major factor preventing RET expansion that respondents identified is the perception that RETs are environmentally unfriendly. They believe RETs pose the risk of negatively impacting land, water, wildlife, and aquatic life. Some respondents expressed their fear that wind turbines will have a negative impact on migratory bird patterns and that hydro dams will affect migratory Arctic char patterns.

The third factor respondents perceived as preventing RET expansion is a lack of creativity and initiative on the part of the territorial and federal government to develop and explore alternative energy sources. One resident explained that from her perspective, the territorial government has been very myopic with regard to developing alternative energy sources in Nunavut. Another resident, a former member of the Nunavut Legislative Assembly, explained that in his political experience, there was inertia in bringing the federal government to the table to discuss alternative energy issues. From a Nunavummiut perspective, a lack of government support for renewable energy has likely hindered future expansion of RETs in the territory.
A fourth factor that respondents believe has delayed RET deployment is that current RETs have not been designed or adapted for northern climates. Respondents who have been exposed to the current (or past) RET systems in Nunavut believe that these projects were unsuccessful because of mechanical failures due to the extreme and unpredictable Nunavut weather conditions. One frustrated Rankin Inlet resident stated, "That damn windmill doesn't work!" She later went on to explain that the community jokes that the turbine turns only when "hotshot politicians visit the community." These unsuccessful RET projects have led residents to question the potential for future success of renewable energy in Nunavut.

An additional factor hindering RET expansion, as identified by Nunavummiut, is a perceived knowledge gap within communities regarding renewable energy. The mayor of one community feels that most Nunavummiut are simply unaware of what alternatives exist and how much these alternatives would cost or benefit the community. A resident in Iqaluit emphasized this point; he thinks residents in some communities might be resistant to renewable energy either because they are not aware of the pros and cons of RETs or have been misinformed. Many respondents believe that this knowledge gap has likely slowed RET expansion in Nunavut.

The final factor noted is a capacity gap within communities related to installing and maintaining RETs. A former Rankin Inlet resident described the many capacity issues associated with the use of the turbine in Rankin Inlet:

\section{I know in Rankin, one of the problems with the windmill... is having enough skilled and trained staff to maintain it. I know that's been a problem and one of the reasons [why] the windmill has been there for over 10 years, but [has] only been operational for a small percentage of that time.}

According to respondents, the ability of communities to support RET installation and maintenance is inadequate and has likely hindered renewable energy expansion in Nunavut.

\section{Positive and Negative Policy Actions Suggested by Respondents}

The final topic discussed in the interviews was what positive policy actions respondents believe that the government should take to support RET expansion, and what policies they believe would have negative effects. Respondents mentioned actions in four categories: (1) policy development, (2) economics, (3) suitable RETs and (4) capacity and knowledge building (Table 1).

Policy Development, the first action category identified by respondents, focuses largely on the importance of involving community members in any future renewable energy discussions in Nunavut. Many respondents suggested specific ways to foster participation, including 
community consultations and public awareness campaigns. These actions, they believe, would address the perceived knowledge gap that residents identified as a factor hindering RET expansion.

The Economics category focuses on ways respondents suggest the government could fund RET projects in Nunavut. These include a greater commitment from government to put capital funding into RET projects and explore partnerships with industry and universities. More programspecific actions identified by respondents included renewable energy rebates and feed-in tariffs. With respect to economics, the only negative action identified by respondents was for the government to raise electricity prices as a result of RET use.

The next category, Suitable RETs, encompasses residents' perceived concerns regarding which RETs should be explored in Nunavut, and how. For instance, on many occasions, respondents identified expanding hydropower and nuclear power as negative actions because they perceive these two technologies as posing the risks of radioactive waste contamination (nuclear) and mercury contamination (hydropower). However, some respondents identified positive actions, such as expanding research in the field of Arctic renewable energy technologies, which in their opinion would alleviate the concern that some residents may have regarding technology not being designed for the North.

The final set of actions identified by respondents, in the Capacity and Knowledge Building category, included policy actions aimed at improving overall RET knowledge in Nunavut to close a perceived knowledge gap in communities. Another action involved increasing the number of trained and skilled RET technicians in Nunavut through education programs. According to one respondent, such a program is already underway at the Nunavut Arctic College.

\section{DISCUSSION}

\section{Overarching Knowledge Gap Regarding Energy}

In discussing the topics of diesel-generated and renewable energy with respondents, it became immediately apparent that many had a limited understanding of anything energy-related, including the current energy system in their community and specific details surrounding renewable energy. However, one subject that respondents were able to discuss frankly was the impact of electricity prices on their families, though this was often only a problem for residents who were also homeowners in the community. This is likely because residents in government-owned housing pay largely subsidized flat electricity rates and therefore are not exposed to the true cost of electricity (McDonald, 2011).

A knowledge gap also emerged regarding the respondents' understanding of the three types of RETs discussed: solar, wind, and hydropower. This gap was especially apparent in discussions involving hydropower, as many respondents were not aware of the various forms of hydropower, and during their interviews, they assumed that all hydropower systems would flood and contaminate the land. The likely cause of this knowledge gap is the limited exposure that Nunavut residents have had to renewable energy.

However, a number of solutions could address this barrier. First, the Government of Nunavut could mitigate the fears of Nunavummiut about the possible impact of RETs on the land, wildlife, and environment by performing environmental assessments (EAs) prior to any RET development to determine the true impact of the technologies. Moreover, these EAs could be combined with extensive community consultations on the subject of renewable energy to increase community awareness of these technologies. Such consultations not only follow the spirit of IQ, but also are an essential part of community-based research, which supports the successful development of policies in Aboriginal communities (Leung et al., 2004; Minkler, 2005). This approach, defined by the Loka Institute (2002), largely entails research "conducted by, for or with the participation of community members." To ensure that these consultations and EAs are being properly understood by the community, government could also undertake followup exercises using deliberative polling: participants would be polled for their views before and after an information session on a technical or ill-understood issue, to determine how exposure to information on an issue changes opinions (Fishkin et al., 2000).

Combining these community consultations and future EAs will likely help to mitigate the knowledge gap that became apparent in our discussions of diesel-generated electricity and renewable energy with various Nunavut residents and might also change community views. Moreover, in addressing this knowledge gap, residents may become more inclined to buy into new renewable energy policies and programs, supporting the principles of Aajiiqatigiingniq and Piliriqatigiingniq.

\section{Frustration with Bureaucratic Barriers}

Another theme that emerged from the interview responses is residents' dissatisfaction with bureaucratic barriers within government that discourage a shift to renewable energy. There was evident frustration among residents regarding the lack of communication between government at various levels and the local residents regarding the Nunavut energy situation, especially in regard to diesel alternatives. This communication breakdown appeared to lead many to detach themselves from the energy problems that exist in Nunavut, while also causing residents, municipal government, and territorial government to work independently rather than together as they explore RETs. In its publication Ikummatiit: The Government of Nunavut Energy Strategy (2007), the Nunavut government outlined a strategy to create an energy system in Nunavut that is affordable, sustainable, reliable, and environmentally responsible (GN, 2007a). A brief discussion of renewable energy introduced the idea of integrating hydropower and residual 
TABLE 1. Potential positive and negative policy actions identified by Nunavummiut.

\begin{tabular}{|c|c|c|}
\hline Category & Positive action & Negative action \\
\hline Policy development & $\begin{array}{l}\text { - Community consultations on RETs } \\
\text { - Public awareness campaigns on RETs } \\
\text { - Including residents in discussions on energy }\end{array}$ & $\begin{array}{l}\text { - Not involving community members in the } \\
\text { development process }\end{array}$ \\
\hline Economics & $\begin{array}{l}\text { - Partnerships with government, industry and university } \\
\text { - Commitment from government to fund RET programs and projects } \\
\text { - Partnerships between homeowners and housing corporations } \\
\text { - Creating government rebates for renewable energy } \\
\text { - Creating feed-in programs for renewable energy } \\
\text { - Developing loan guarantees through P3 financing }\end{array}$ & - Raising electricity prices \\
\hline Suitable RETs & $\begin{array}{l}\text { - Building transmission line connecting Manitoba grid to Nunavut } \\
\text { - Increasing research on technologies, especially Arctic RETs }\end{array}$ & $\begin{array}{l}\text { - Using nuclear power generation } \\
\text { (concerned about radioactive waste) } \\
\text { - Using hydropower } \\
\text { - Continuing to use diesel } \\
\text { - Using technologies that will impact rivers, } \\
\text { land or wildlife }\end{array}$ \\
\hline Capacity and Knowledge Building & $\begin{array}{l}\text { - Develop RET Technician Training Program (at the Arctic College) } \\
\text { - Increase awareness of energy conservation in Nunavut }\end{array}$ & \\
\hline
\end{tabular}

heating in Nunavut communities and stressed the importance of energy efficiency and energy reductions across the territory. Nonetheless, there has been little movement toward implementing the renewable energy actions outlined in the Energy Strategy.

\section{Reluctant Acceptance of Diesel Energy}

Finally, the results of the interviews exposed what can be defined as a reluctant acceptance of diesel energy by communities. Though respondents indicated that they were greatly dissatisfied with the current energy situation in Nunavut, the manner in which they responded revealed that they have in fact accepted diesel energy, despite the negative environmental, health, economic, and social concerns. These concerns are supported by the literature, which shows that diesel generators and engines have been linked to polluting the air, water, and soil in the region (Lloyd and Cackette, 2001). However, one can assume that the reason residents have accepted diesel energy with all its drawbacks is that electricity is a necessity in the North: one cannot live comfortably in such extreme conditions without it. It should, nevertheless, be noted that within the largely defeatist atmosphere, a sense of optimism lingered among residents because alternatives exist that could improve their quality of life and that of future generations. This optimism is likely propelled by the small-scale success of renewable energy pilot projects in Rankin Inlet and Iqaluit.

\section{The Importance of Renewable Energy Economics In Nunavut}

Cost was a theme that emerged continually throughout the interviews with Nunavummiut on renewable energy, probably because energy already takes up about $20 \%$ of the Government of Nunavut's annual budget, and electricity prices in Nunavut are about five to ten times higher than those in southern Canada (GN, 2007a; GNWT, 2008; CBC, 2011a; QEC, 2011b). Moreover, the high cost of electricity and diesel in Nunavut can limit the funding available for other daily necessities such as health services, food security, and education (Anon., 2008; NTI, 2008, 2009; GN, 2009, 2010; Egeland et al., 2010; McDonald, 2011).

Consequently, interview respondents often shifted the discussion to focus on the economics of energy, which included maintaining or lowering living costs in Nunavut. Moreover, with the recent $19 \%$ rate increase across the territory, diesel-generated electricity prices in Nunavut will likely become an even greater economic burden on homeowners and residents, while also putting greater economic pressure on government to subsidize electricity prices (CBC, 2011b; Windeyer, 2011). For this reason, the greatest qualm that residents have about future renewable energy in Nunavut is the potential for further electricity rate increases.

Therefore, to gain community approval of renewable energy, full-scale economic analyses must be performed for various RETs across the territory. Life-cycle economic analysis can show that the levelized cost of electricity (LCOE) from RETs can in fact be lower than that of electricity generated from diesel fuel. The LCOE method considers the lifetime generated energy and costs to estimate a price per unit of energy generated. Already the costs of wind, solar, and hydro energy in southern Canada are substantially below what residents in Nunavut pay for diesel (Wiser and Bolinger, 2008; Hydro Québec, 2010; Branker et al., 2011). LCOE studies of RETs deployed at the MWscale specifically in Nunavut are needed to show residents that they will not incur any additional electricity costs and in fact may considerably reduce energy-related costs compared to diesel fuel.

\section{Including IQ in Policy Research and Development}

The Nunavut population is largely Inuit $(85 \%$ of the population); consequently there is a strong traditional and 
cultural Inuit influence within communities. Therefore, an important part of community-based research in Nunavut is ensuring that Inuit Qaujimajatuqangit is incorporated into research and policy development. IQ can be defined as knowledge "communicated from elders to younger Inuit at a very early age through stories, songs, direct modeling of behaviour and legends that spoke of the success associated with remembering them" (GN, 2005). Not surprisingly, during the interviews, many respondents formulated their perspectives on solar, wind, and hydropower from their knowledge of the local natural resources in the region, including solar and wind patterns, rivers, and waterways. Therefore, exploring how a community's IQ can be incorporated into renewable energy research and policy development could be very beneficial, since many Nunavummiut have a strong knowledge of their land and natural resources. Their ancestors lived completely off of the land, using only renewable energy and local sources. Now efforts are being made to replicate these old ways of living while maintaining the benefits of modern society.

\section{FUTURE WORK}

While the results of the interviews undertaken in this research have exposed a number of important issues that must be addressed to successfully integrate renewable energy in Nunavut, future research should expand the scale of the interviews. Increasing the number of interviews with Nunavummiut will allow future research to explore more perspectives and perform a more comprehensive analysis of challenges, opportunities, and actions. Moreover, given that social and environmental conditions vary from community to community, the scope of the interviews should be expanded to include the leaders of all Nunavut communities. From these data, an extensive assessment could be made of how each community would likely address the expansion or introduction of renewable energy at a municipal level.

While it is essential to understand local perspectives of renewable energy in Nunavut, it is equally important to explore the perspectives of the various government departments that are involved in northern renewable energy through federal and territorial policy-makers and government consultants. Further interviews are being undertaken with a number of key government policy-makers to determine what challenges and opportunities exist from a policy perspective. Combined, these results will help guide policymakers as they develop and shape new and more successful renewable energy policy in Nunavut and across the Arctic. Finally, to ensure that these new policies adequately address the needs of the communities, further studies should be undertaken beyond the preliminary investigation that established the technical viability of wind and solar energy for Nunavut (McDonald et al., 2012). These studies should provide high-resolution data on natural resources (e.g., solar radiation and wind speeds) and maps of rivers and other waterways that will allow planners to optimize RET system design for Nunavut. A comprehensive understanding of the current natural resources will help in developing policies for different regions based on the available resources.

\section{ACKNOWLEDGEMENTS}

The authors would like to thank the residents of Iqaluit, Rankin Inlet, and Resolute Bay for their participation in this study, TD Canada Trust and NSERC for funding this project, and the Government of Nunavut for its support throughout the project.

\section{REFERENCES}

Abelsohn, A., Stieb, D., Sanborn, M.D., and Weir, E. 2002. Identifying and managing adverse environmental health effects: 2. Outdoor air pollution. Canadian Medical Association Journal 166(9):1161 - 1167.

Anon. 2008. Health inequalities: A matter of social justice. Canadian Public Health Associate 2008 Annual Conference, 1-4 June 2008, Halifax, Nova Scotia. The Daily Newsletter, June 1 (Issue 1). 4 p.

Arent, D.J., Wise, A., and Gelman, R. 2011. The status and prospects of renewable energy for combating global warming. Energy Economics 33(4):584-593.

Ascher, A. 2002. North wind: Nunavut and Yukon are hoping wind turbines will reduce dependency on diesel plants. Alternatives Journal 28(4).

Boulet, L.-P., Becker, A., Bérubé, D., Beveridge, R., and Ernst, P. 1999. Canadian asthma consensus report, 1999. Canadian Medical Association Journal 161(11, Suppl. 1). 62 p.

Branker, K., Pathak, M.J.M., and Pearce, J.M. 2011. A review of solar photovoltaic levelized cost of electricity. Renewable and Sustainable Energy Reviews 15(9):4470-4482.

CACP (Canadian Asthma Consensus Group). 1999. Provocative factors in asthma. Canadian Medical Association Journal 161(11, Suppl. 1):S8-S14.

CanmetENERGY. 2005. An introduction to micro-hydro power systems. Report. Ottawa: Natural Resources Canada. http:// canmetenergy.nrcan.gc.ca/renewables/small-hydropower/ publications $/ 2730$.

. 2009. Renewables: Wind energy. Ottawa: Natural Resources Canada. http://canmetenergy.nrcan.gc.ca/renewables/ wind/2171.

CBC (Canadian Broadcasting Corporation). 2011a. Electricity in Nunavut. CBC News, April 9. http://www.cbc.ca/news/canada/ story/2011/04/09/f-territory-energy-profile-nunavut.html.

- 2011b. Nunavut power rates going up 19\%. CBC News, March 30. http://www.cbc.ca/news/canada/north/ story/2011/03/30/qulliq-energy-rate-increase.html.

Ciencewicki, J., and Jaspers, I. 2007. Air pollution and respiratory viral infection. Inhalation Toxicology 19(14):1135-1146. 
Dignard-Bailey, L., Martel, S., and Ross, M.M.D. 1998. Photovoltaics for the North: A Canadian program. Varennes, Quebec: Natural Resources Canada.

GN (Government of Nunavut). 2001. Inuit knowledge of climate change: A sample of Inuit experiences of climate change in Nunavut. Baker Lake and Arviat, Nunavut. Iqaluit: Government of Nunavut.

Egeland, G.M., Pacey, A., Cao, Z., and Sobol, I. 2010. Food insecurity among Inuit preschoolers: Nunavut Inuit Child Health Survey, 2007-2008. Canadian Medical Association Journal 182(3):243-248.

Fishkin, J.S., Luskin, R.C., and Jowell, R. 2000. Deliberative polling and public consultation. Parliamentary Affairs 53(4):657-666.

Ford, J.D., and Smit, B. 2004. A framework for assessing the vulnerability of communities in the Canadian Arctic to risks associated with climate change. Arctic 57(4):389-400.

Freeman, M.M.R., and Carbyn, L.N., eds. 1988. Traditional knowledge and renewable resource management in northern regions. Edmonton, Alberta: Boreal Institute for Northern Studies.

GN (Government of Nunavut). 2001. Inuit knowledge of climate change: A sample of Inuit experiences of climate change in Nunavut. Baker Lake and Arviat, Nunavut. Iqaluit: Department of Sustainable Development.

- 2003. Nunavut climate change strategy. Iqaluit: Department of Sustainable Development.

—.2005. Inuit Qaujimajatuqangit(IQ). Iqaluit: Department of Human Resources. http://www.gov.nu.ca/hr/site/beliefsystem. htm.

2007a. Ikummatiit: The Government of Nunavut energy strategy. Iqaluit: Department of Executive and Intergovernmental Affairs.

—. 2007b. A Discussion Paper for Ikummatiit: An energy strategy for Nunavut. Iqaluit: Energy Secretariat.

- 2008a. Culture. Iqaluit: Government of Nunavut. http:// www.gov.nu.ca/files/Culture.pdf.

. 2009. Nunavut maternal and newborn health care strategy 2009-2014. Iqaluit: Department of Health and Social Services.

- 2010. Fiscal and economic outlook. Iqaluit: Department of Finance Nunavut.

GNWT (Government of Northwest Territories). 2008. Electricity rates for 1,000 kW.h in North America (in cents per kW.h). Yellowknife: Centre for Geomatics, GNWT.

Hall, B.L. 1992. From margins to center? The development and purpose of participatory research. The American Sociologist 23(4):15-28.

Hydro Québec. 2010. Comparison of electricity prices in major North American cities. Montreal: Hydro Québec. http://www. hydroquebec.com/publications/en/comparison_prices/pdf/ comp_2010_en.pdf.

IPCC (Intergovernmental Panel on Climate Change). 2008. In: Climate change 2007: Synthesis report. Cambridge: Cambridge University Press.

Israel, B.A., Eng, E., Schulz, A.J., and Parker, E.A., eds. 2005. Methods in community-based participatory research for health. San Francisco: Jossey-Bass.
Janssen, R., and IEA Renewable Energy Working Party. 2002. Renewable energy...into the mainstream. Sittard, Netherlands: IEA REWP.

Joint Ventures Ltd. 2003. Bathurst Inlet Port and Road Project. Yellowknife: Joint Ventures Ltd.

Laumann, E.O., and Knoke, D. 1987. The organizational state: Social choice in national policy domains. Madison: The University of Wisconsin Press.

Leung, M.W., Yen, I.H., and Minkler, M. 2004. Community based participatory research: A promising approach for increasing epidemiology's relevance in the 21st century. International Journal of Epidemiology 33(3):499-506.

Lloyd, A.C., and Cackette, T.A. 2001. Diesel engines: Environmental impact and control. Journal of the Air \& Waste Management Association 51(6):809-847.

Loka Institute. 2002. About the CRN: What is community-based research? Washington, D.C.: The Loka Institute. http://www. loka.org/crn/About\%20CRN.htm.

London Economic Press. 2004. Nunavut: Fact sheet. Boston: London Economic Press.

McDonald, N.C. 2011. Exploring local Nunavut perspectives on renewable energy expansion. Public Sector Digest, April 1.

McDonald, N.C., and Pearce, J.M. 2012. Renewable energy policies and programs in Nunavut: Perspectives from the federal and territorial governments. Arctic 65(4):465-475.

McDonald, N.C., Nguyen, H.T., and Pearce, J.M. 2012. Technical feasibility of renewable electricity generation in Nunavut. In: Tiwari, M.D., and Vaish, A., eds. Green energy. Aalborg, Denmark: River Publishers. 41-74.

McLaughlin, D.V.P., McDonald, N.C., Nguyen, H.T., and Pearce, J.M. 2010. Leveraging photovoltaic technology for sustainable development in Ontario's First Nations communities. Journal of Sustainable Development 3(3):3-13.

Mikkelsen, B. 2005. Methods of development work and research: A new guide for practitioners. London: Sage Publications.

Miles, M.B., and Huberman, A.M. 1994. Qualitative data analysis: An expanded source book. Beverly Hills: Sage Publications.

Minkler, M. 2005. Community-based research partnerships: Challenges and opportunities. Journal of Urban Health $82(2$, Suppl. 2):ii3-ii12.

Nova Scotia Department of Energy. 2010. Community Feed-in Tariff Program. Halifax: Department of Energy. http://www. nsrenewables.ca/feed-in-tariff.htm.

NRCan (Natural Resources Canada). 1998. Renewable energy in Canada's remote communities - Pre-feasibility studies of potential projects. Varennes: CANMET.

NTI (Nunavut Tunngavik Incorporated). 2001. Elder's conference on climate change: Final report. Cambridge Bay: NTI.

- 2008. Nunavut Adult Learning Strategy. Iqaluit: Department of Health and Social Services.

- 2009. Recruitment and retention of Inuit nurses in Nunavut. Report prepared by Aarluk Consulting Inc., March 2009, on behalf of NTI. Iqaluit: Department of Health and Social Services.

Nunavut Power. 2002. Wind power generation. Iqaluit: Government of Nunavut. 
OPA (Ontario Power Authority). 2008. Facilitating the development and use of renewable energy and enabling 2010 and 2025 renewable targets. Toronto: OPA. http://www.powerauthority. on.ca/sites/default/files/page/6448_E-2-2_corrected_080505_ mm_.pdf.

2010. FIT Program. Toronto: OPA. http://fit.power authority.on.ca/fit-program.

Patton, M.Q. 1990. Qualitative evaluation methods, 2nd ed. Newbury Park: Sage Publications Inc.

Pearce, J.M. 2002. Photovoltaics: A path to sustainable futures. Futures 34(7):663-674.

- 2006. Service learning in engineering and science for sustainable development. International Journal for Service Learning in Engineering 1(1):1-4.

QEC (Qulliq Energy Corporation). 2011a. Qulliq Energy Corporation 10th Annual Report. http://www.nunavutpower. com/home/index.php?option $=$ com_docman\&task $=$ doc download\&gid $=762$.

2011b. April 2011 rate schedule. Iqaluit: QEC.

Ross, M.M.D, and Usher, E.P. 1995. Photovoltaic array icing and snow accumulation: A study of a passive melting technology. Proceedings of the 21st Annual Conference of the Solar Energy Society of Canada, Toronto, Ontario, 31 October-2 November 1995. $21-26$.
Sigaud, S., Goldsmith, C.A., Zhou, H., Yang, Z., Fedulov, A., Imrich, A., and Kobzik, L. 2007. Air pollution particles diminish bacterial clearance in the primed lungs of mice. Toxicology and Applied Pharmacology 223(1):1 -9.

Smitherman, G. 2009. Bill 150, Green Energy and Green Economy Act, 2009. Toronto: Legislative Assembly of Ontario. http://www.ontla.on.ca/web/bills/bills_detail.do?locale $=$ en $\&$ BillID $=2145$.

St. Denis, G., and Parker, P. 2009. Community energy planning in Canada: The role of renewable energy. Renewable and Sustainable Energy Reviews 13(8):2088-2095.

Tammelin, B., and Seifert, H. 2001. Large wind turbines go into cold climate regions. Proceedings of the European Wind Energy Conference, 2-6 July 2001, Copenhagen, Denmark.

Weir, E. 2002. EPA links diesel exhaust, lung cancer. Canadian Medical Association Journal 167(7):795.

Windeyer, C. 2010. A wind turbine designed with the Arctic in mind. Nunatsiuq News, September 27.

- 2011. Nunavut municipalities slam power rate hike. Nunatsiaq News, April 6.

Wiser, R., and Bolinger, M. 2008. Annual report on U.S. wind power installation, cost, and performance trends: 2007. Washington, D.C.: U.S. Department of Energy. 